\title{
Virtual meeting ground for colonial (re)interpretation of the Banda Islands, Indonesia
}

\author{
JOËLLA VAN DONKERSGOED
}

\begin{abstract}
The history of the Banda Islands is revealed in material and immaterial heritage which can still be narrated, visited and experienced today. Using the technological tools available in the Digital Humanities, this paper proposes a project to create a virtual interactive platform in which documents and stories related to the colonial past can be gathered. Tools like crowd-sourcing and crowd-mapping can be used to establish this archive from the bottom-up, creating a platform allowing both the former colonizer and colonized to reflect on the past. Moreover, it will provide scholars with a source of information to revisit the history of the Banda Islands. This particular history is part of the current public debate in the Netherlands regarding the colonial past, moreover, it is central to the narrative concerning the ongoing conservation efforts to prepare the islands' heritage to become an UNESCO World Heritage site for Indonesia.
\end{abstract}

KEYWORDS

Crowd-sourcing; Digital Humanities; colonial heritage; Banda Islands; Indonesia.

\section{INTRODUCTION}

Heritage is a broad concept which encompasses both material and immaterial aspects of culture, and one of its defining characteristics is that it connects the past to the present through the ongoing practice of interpretation by contemporary society. In this paper, ${ }^{1}$ I discuss how the past events in the

1 I want to acknowledge several people that have been crucial to the development of the idea

JOËLLA VAN DONKERSGOED is PhD candidate in Cultural Heritage and Preservation Studies at Rutgers University, USA. Her publications include "Intangible culture as the prime asset of a cultural landscape; Case study of the Banda Islands, Indonesia", in: Charlotte Waelde (ed.), Research handbook on contemporary intangible cultural heritage; Law and heritage (Cheltenham: Edward Elgar Publishing, 2018: 363-378); "Reinterpretations at Fort Nassau, Banda Islands in Indonesia", IIAS Issue 80 (2018: 40). The fields of her research interest are Cultural Heritage Management, Indonesia, and Dutch Colonial Heritage. Joëlla van Donkersgoed may be contacted at: j.van.donkersgoed@rutgers.edu.

(C) 2019 Faculty of Humanities, Universitas Indonesia

JOËLLA VAN DONKERSGOED| DOI: 10.17510/wacana.v20i2.731. 
Banda Islands in Indonesia have resulted in the formulation of heritage by multiple agents, each with their own perspective. These include local voices from the Banda Islands, but also those groups which have been displaced and the (descendants of the) former perkeniers who still feel connected to the history and heritage of the islands. Using technological tools from the digital humanities, I propose that it is possible to gather and display information from these various actors on a virtual platform, paving the way for a conversation which might aid in the ongoing debate on how to deal with post-colonial heritage, as exemplified in the case of the commemoration of Jan Pieterszoon Coen in the Netherlands.

As the present residents of the Banda Islands will proudly proclaim, this small archipelago in the province of Maluku in modern-day Indonesia were once in great demand for their spices, as it was here the best quality nutmeg and mace were produced (see Figure 1).

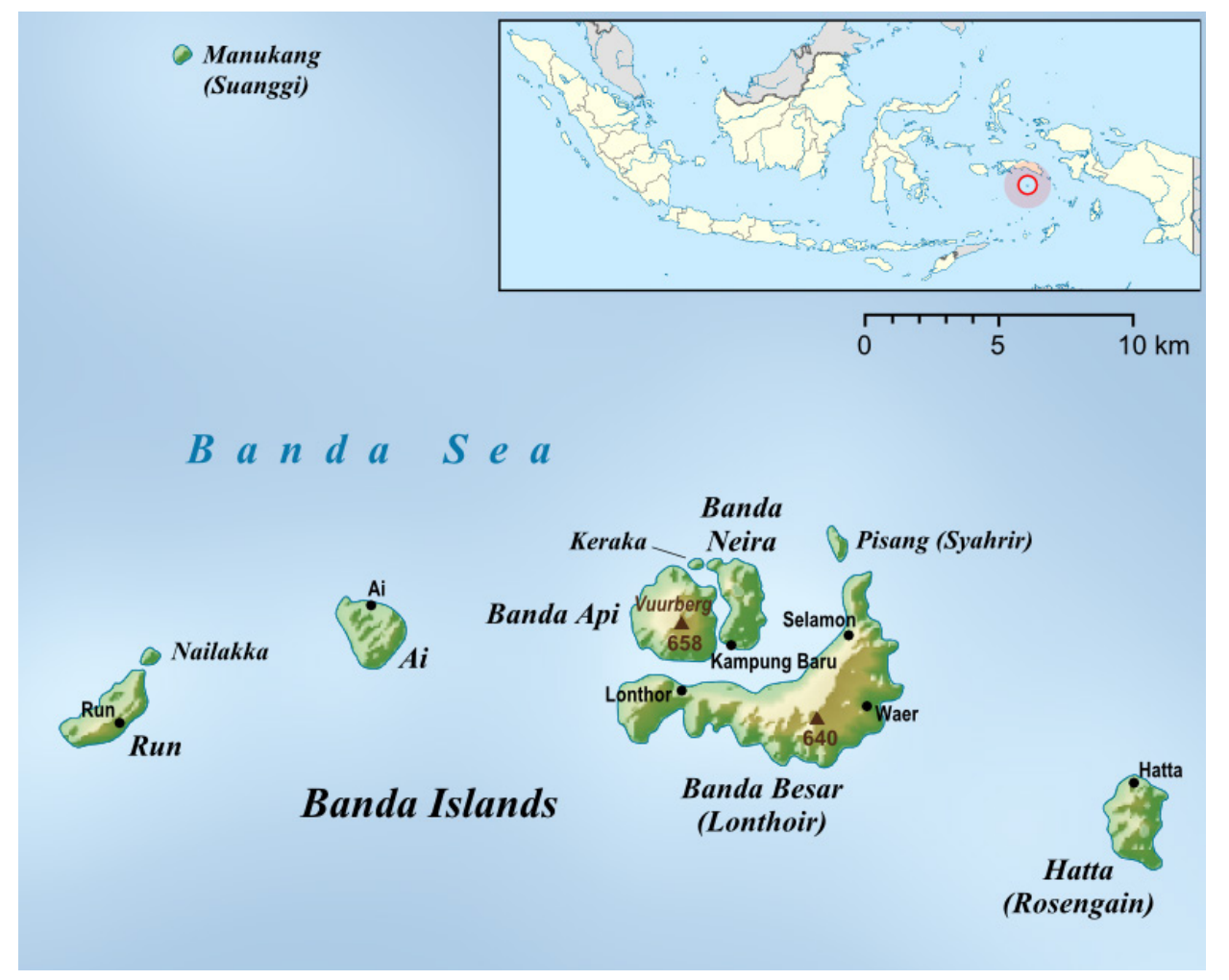

Figure 1. Map of the Banda Islands. (Made by Lencer CC BY-SA 3.0.). ${ }^{2}$

presented in this paper. Therefore, I would like to thank Tanya Des Alwi, Rachel de Vries, Ace Suares, Milo van der Linden, and the team of Openstreetmap Indonesia for their inspiration and support of this article. Last, but not least, I want to thank the residents of the Banda Islands for welcoming me into their midst and the Andrew W. Mellon Foundation which has supported my fieldwork financially.

2 Publicly available at: https://commons.wikimedia.org/wiki/File:Banda_Islands_ en.png\#filehistory (accessed on 19-4-2018). 
Hence the Banda Islands functioned as a central location in an early interisland trade network, and the trade in nutmeg also attracted merchants from faraway places like the Arabian Peninsula and China. As nutmeg gained in popularity in Europe, Portuguese, Spanish, English, and Dutch merchants went out in search of these "spice islands". In short, when the Dutch East India Company (Vereenigde Oostindische Compagnie, VOC) was established, one of its main objectives was to seize these islands to secure a monopoly on the production and trade in nutmeg (Gaastra 1991). In 1621, under the command of Jan Pieterszoon Coen, this nutmeg monopoly was forcibly established by the massacre of forty-four orang kaya, prominent figures in the community, and the ensuing raiding, enslavement and deportation of the native population; pursued to a point at which the islands were virtually depopulated.

This brief introduction serves not only to show the importance of these islands in the history of multiple nations, but also to draw attention to one of the most discussed and prominent narratives of these islands: the Bandanese massacre of 1621. The bloody conquest by the Dutch is one of the darker passages of Dutch national history which are currently being revisited in an effort to raise awareness on this negative history and heritage of the Netherlands. Pertinently, this violent history is regarded as the commencement of an enduring Dutch colonial presence in the Banda Islands, which lasted over 300 years. During this time, the Dutch colonists and their subordinates built military, religious, civil, and agricultural structures in their efforts to establish a productive and secure society. These buildings still dominate the view of many neighbourhoods and have become part of everyday life on the islands. The remnants of the Dutch colonial constructions which are part of the landscape of the Banda Islands are regarded as material heritage. However, the field of heritage management is not merely interested in these physical historical remnants of the past. Perhaps even more important is the acknowledgement that heritage is a value given to properties by people, and therefore not necessarily an objective value. This point of view can be taken quite far, as heritage scholar Laurajane Smith famously stated that: "All heritage is intangible" (Smith 2006), meaning that tangible heritage should be studied with an emphasis on the attributed intangible values. Her critical stance is one of the principal motors in the current field of heritage studies which has reoriented itself on the meanings to be provided to heritage sites by (local) communities.

In this article, I discuss how technological bottom-up tools, like crowdsourcing and crowd-mapping, can assist in identifying, marking, and archiving these attributed values of tangible heritage. Through the participatory aspect of these digital tools, these methods as promoted by the Digital Humanities create a platform from which to present different perspectives on history and heritage. In this article, the Banda Islands feature as a case study which exemplifies how varied these values can be, as multiple interpretations of the past can co-exist in reality. Moreover, as the particular instance of the Banda massacre shows, the narratives attached to sites can be re-evaluated and 
assume new values in contemporary debates, like the ongoing discussions in the Netherlands about how its colonial legacy is presented to, and experienced by, the public.

\section{Historical OVERVIEW BANDA IsLands}

For the purpose of this paper, I give a brief historical overview from roughly the 1620s to the 1950s; the time at which the Banda Islands were under Dutch rule. As I mentioned in the introduction, the year 1621 is especially significant for the contemporary Bandanese and all those who are interested in the history and heritage of the Banda Islands. In late April 1621, a suspected complot against the Dutch by the Bandanese residents was all the provocation which Jan Pieterszoon Coen needed to initiate a pre-emptive counter-attack (Chijs 1886: 138-141). Not only were forty-four orang kaya decapitated for their alleged participation in the conspiracy but, on the orders of Jan Pieterszoon Coen, the islands were raided and their residents enslaved and deported, or killed outright.

Some people managed to flee the atrocities, and one particular group was able to resettle in the neighbouring Kei Islands (Masyarakat Waer-Ohoitel 2014: 9-10). The residents of these islands are nowadays referred to as orang Banda asli, the original, or native, Bandanese people. This group continues to sing and narrate the oral history of Banda, and they adhere to certain cultural traditions like pottery-making which have been lost on the islands themselves. Although the remaining "original Bandanese" reside in the Kei Islands, some of the Bandanese traditions have also been continued by the immigrant population. These traditions are therefore tied not so much to ancestry, but rather attached to the land and the spirits which dwell on the Banda Islands (Winn 2005; Kaartinen 2010).

Jan Pieterszoon Coen's depredations left the islands practically depopulated, with insufficient numbers of people to continue the nutmeg production for the VOC. However, it might be claimed that this was the actual assignment of the VOC, as L'Hermite de Jonge suggested to the Heeren XVII in 1611 that "the most effective way to obtain a nutmeg monopoly was to destroy the 'bothersome' population and repopulate the islands with colonists who would be serviced by slaves" (Van de Wall 1934: 519). This quote describes the actions which were carried out by Coen, as the VOC granted rights to run the nutmeg gardens to ex-employees; the plots of land were called perken, those who ran them perkeniers, and their slaves who worked the land or served the perkeniers perkhorigen. Nevertheless, the re-population of the Banda Islands presented the Company with a problem and it initiated policies to encourage freemen of Chinese, Ambonese, and other Moluccan descent to settle in Banda alongside the established perkeniers (Van de Wall 1934: 517). Moreover, Jan Pieterszoon Coen imported slaves to the Banda Islands from different regions, most notably from Makassar, Bugis, Malay, and Java, to work as perkhorigen (Masyarakat Waer-Ohoitel 2014: 9). Van der Wall even states that there were also expeditions mounted from the Banda Islands to the Kei and Aru Islands 
which hunted down hundreds of natives and brought them to Banda to perform slave labour (Van de Wall 1934: 548-549).

It was hard to repopulate the islands, despite various ordinances designed to promote migration to the Banda Islands and to keep people there once they had arrived (Van de Wall 1934: 545-547). For example, men were not allowed to leave the islands to return to the Netherlands to find a wife and get married. This restriction posed a problem and, as they were not allowed to marry Indonesian women either, many illegitimate children were born. After Coen's death the VOC changed its policy and even promoted the intermarriage of white colonists with native people, as it claimed that these mixed breeds had proven to be more resilient to the life in the Indies (Van de Wall 1934: 556). Beset by suchlike problems, the Banda Islands did not develop into the trading colony, as Coen envisaged; it would be more proper to call it a farming colony, as the stated objective was to produce the spices for the Company. These references to the importation of slaves, enticements for freemen to settle in Banda and the regulations regarding intermarriage are important to the current demography of the Bandanese residents.

Officially, ownership of the perken was not vested in the perkeniers who were merely the vassals of the VOC which was the owner of the land and controlled its usufruct (Van de Wall 1934: 525-527). Nevertheless, in practice, the perkeniers perceived themselves a lords and masters of their properties, on which they bestowed names if they were their own estates and they were inherited from generations to generation (Van de Wall 1934: 535). Besides the production of nutmeg for the VOC, the perkeniers are said to have used their private slaves for fishing and the cultivation of vegetables and fruit which could be sold for their personal profit (Wright 1958: 17). Hanna and Winn have both claimed that the perkeniers also dabbled in the inter-island trade with their own trading vessels. This assertion is made on the basis of Hanna's translation of Francois Valentijns account: "the stoutest and fastest boats which one might wish and voyage on them to distant islands" (Hanna 1978: 75; Winn 2010: 375). However, this interpretation is based on a mistranslation of the original text, which actually states that the perkeniers owned "the fattest and most beautiful sheep, which they shipped from other southern islands" (Valentijn 1856: 15). ${ }^{3}$ It does, however, indicate that there was contact between the different island groups and trade was conducted with the perkeniers, although here it refers to import rather than export.

The lifestyle of the perkeniers, especially in years of surplus, was remarked upon. For example, Augusta de Wit describes that, a few years before the 1870s, the price of nutmeg and mace was so high ( $f 300$ for mace and $f 170$ for nutmeg per pikol $\left.^{4}\right)$ that the perkeniers splashed out on conspicuous consumption: one

\footnotetext{
3 "Zij hebben de schoonste en vetste schapen, die men wenschen kan, die zij van Zuidooster eilanden krijgen en verder velerlei vee op hun erf lopen," which translates as: "they have the most beautiful and fattest sheep that a man could wish for, which they get from the southeastern islands and furthermore various breeds of cattle roam their properties.' The Dutch word schapen, plural for sheep, was probably mistaken for the plural of ships, which is schepen.

4 A pikol is an old Malay unit, defined as the weight that a man can carry. This can be defined
} 
tiled his floor with rijksdaalders, another ordered ice from Norway to cool his champagne and yet another wanted to hear the croaking frogs from the Netherlands which he had once heard his grandfather describe (Wit 1914: 418). This "golden" era did not last long, and when De Wit visited the islands she describes them as dead and silent, as the price for mace had dropped to $f 170$ and nutmeg only fetched $f 25$ per pikol. Besides the task of producing nutmeg for the VOC, the perkeniers were expected to maintain the fortifications which were located across the islands (Van de Wall 1934: 543-544). Their instructions informed them that the walls had to be whitewashed, plastered, and cleansed of grime. The perkeniers were also tasked with the maintenance of the roads and the stairs, particularly the stairs in Banda Besar which are still used as the primary means of ascending to the higher elevations.

On 1 January 1860, slavery in the Banda Islands was abolished, which was formally announced to a crowd of 1,122 slaves gathered at the governor's residence (Van den Berg 1995: 42-43). This moment is one of the few in which historical sources hint at the experiences of the perkhorigen. Pertinently, even though they were offered two years' worth of wages and $f 4$ per month if they signed up to continue their work on the plantations, an eerie silence prevailed. Only seventy-three slaves actually signed up to remain in the service of their former masters. One anecdote which describes the eagerness for freedom of the perkhorigen and the subsequent desolation of the perkeniers was recorded by Augusta de Wit, who writes that on 31 December 1859, the slaves had already packed and men, women, and children were waiting for the clock to strike twelve which would make them free men (Wit 1914: 417). The next day, the perkeniers were chopping their own wood and collecting their own water, while their wives were pounding rice for their meals: a sight never before seen. The slave labourers were replaced by freemen and convict labourers (Crawfurd 1856: 36). The use of convict labour was not new, as the Banda Islands had been used as a penal settlement and forced labour camp for prisoners before. This is shown by the figures in Crawfurd's description of 1840, in which he mentions that there were 1,029 convicts from Java, Sumatra, and Borneo on Banda (Crawfurd 1856: 34).

The abolition of slavery was not the only major change in this decade but, because of the continued financial straits of the perkeniers, in 1864 the Dutch Trade Company (Nederlandsche Handel-Maatschappij, NHM) decreed that the monopoly on the spices would be terminated (Hanna 1978: 116). The decree became only partially effective in 1865 , as the perkeniers did not have any personal experience in conducting trade as they were accustomed to dealing with just one buyer, who would take care of the logistics of storage, transportation, and selling the spices on the market in Amsterdam. The NHM continued to function as the middlemen until 1873, when the termination of the nutmeg monopoly became fully effective. The fact that the monopoly had existed this long is remarkable, as Crawfurd notes in 1856:

in modern measurements as 60 kilogram or 132 pounds. 
In fact this monopoly, which is now existing for above two centuries, if the cost of its acquisition be reckoned, never could have yielded real profit, and for many years back is well known to have been accompanied by a heavy loss. A perseverance in it, therefore, is a subject of much surprise both to the enlightened Dutchmen and strangers. (Crawfurd 1856: 35).

As the profits from the Banda Islands diminished, their importance to the colonial government declined as well (Hanna 1978: 120-121). This is visible in the level of administration stationed in Banda Neira, which was at its highest level, that of governor, during the VOC era, and downgraded when the NHM settled on a resident to report back to the Netherlands. It finally sunk to the level of controleur in 1866, a junior position whose incumbent had to report to the resident in Ambon. This last administrative change meant that most officials moved to Ambon, and many perkeniers followed them, leaving the Banda Islands politically impoverished (Van den Berg 1995: 110-112).

"There are no Bandanese [people] left" was a phrase uttered by the famous writer Eduard Douwes Dekker, better known under his pseudonym Multatuli, when he wrote about the genocide of 1621 (Multatuli and Stuiveling 1950: 604-617). Historian Joop van den Berg rightly corrects this exclamation, by noting that there are again 15,000 people living in the Banda Islands who proudly call themselves Bandanese (Van den Berg 1995: 13). Today the population has grown to 20,000 people, spread across the various islands. The mixed demography, including the Chinese and Arab merchants, was further diversified as the Banda Islands functioned as a place of banishment for those who opposed the Dutch colonial government throughout the Dutch East Indies from 1710. Most notably, as resistance against the colonial regime increased over the years, the revolutionary Dr Tjipto Mangoenkoesomo was exiled to the islands in 1927 (Van den Berg 1995: 115-117). In 1936, he was followed by the nationalists Mohammed Hatta and Sutan Sjahrir, who became the first vice-president and prime minister of Indonesia when Mohammed Hatta and Sukarno proclaimed Indonesian independence on 17 August 1945. During their exile, Hatta and Sjahrir set up a free school and found time to continue their studies and writings. One of the observations which Sjahrir made about the Bandanese population at that time was that he suspected that the Indonesian blood was dominant in all inhabitants, whether of "Arab", "Chinese" or "European" descent (Sjahrir 1946). The exile of these prominent independence fighters to the Banda Islands brings us back to the earliest part of history which I have narrated here, the resistance of the local Bandanese to the Dutch intention to take over their resources and trade.

\section{Public debate concerning Jan Pieterszoon Coen}

One central figure embroiled in the events of 1621, when the monopoly on the trade of nutmeg and mace was established by violence, is Jan Pieterszoon Coen. At the beginning of the year 2018, a fierce public debate about the commemoration of the Dutch colonial past was triggered by the removal of a replica bust of Maurits van Nassau from the Mauritshuis in The Hague 
and the initiative to rename the primary school, now called Jan Pieterszoon Coen-school, in the "Indonesian" neighbourhood of Amsterdam. In the media, these initiatives were dubbed the "Nieuwe Beeldenstorm", suggesting that a new burst of iconoclasm had erupted as references to the Dutch colonial past were being removed from the public sphere.

Before delving into the acts of commemoration connected to Jan Pieterszoon Coen, I shall briefly discuss the term Nieuwe Beeldenstorm which refers to the Dutch iconoclasm: a violent revolt against the religious narrative which the Roman Catholic church imposed on the people. It exhibited itself by groups of Protestants entering Roman Catholic churches and destroying the depictions of saints and other items of religious significance in 1566 at the outbreak of the Dutch revolt against Spain. The present movement to which this term refers merely advocates a more inclusive history and a need to acknowledge the negative history which has contributed to the wealth of Dutch society today. So far, its proponents have not taken up sledgehammers and ropes to disfigure and tear down statues of personages who are related to these histories. Moreover, as Gert Oostindie has indicated during his Daendelslezing, there are only few of these physical statues in the Netherlands (Oostindie 2018). Rather than physical violence, the present-day effect is that institutions are reflecting on the narrative they are producing and evincing a willingness to include more perspectives on the history. However, the critique against this movement to re-address this past has been described as "moral vanity with which slavery is now judged, which indicates a lack of historical awareness" (Navis 2018). Rather than a "lack of historical awareness", I would claim that revisiting this past to include the voice of the suppressed and colonized is creating a more complete understanding of history, and this movement should therefore be encouraged.

For this article, I shall zoom in on the example of the historical figure of Jan Pieterszoon Coen. Throughout the sources which I have studied, there seems to be an overall consensus which acknowledges the gruesome acts for which Coen was responsible in his efforts to establish a Dutch foothold in Indonesia, and he has been referred to by his nickname the "Slaughterer of Banda" (Tulkens 2007: 10). Moreover, as my research has taken me through older historical accounts of the history of the Banda Islands, I have found several instances in which the authors speak unfavourably of his conduct. In his 1886 account, Van der Chijs states: "If a statue had not yet been erected for Jan Pieterszoon Coen, I doubt it would ever have been. His name is tainted with blood". Van der Chijs is referring here to the statue which was put up in the main square of Hoorn, the city in which Jan Pieterszoon Coen was born (see Figure 2).

Whether this statue should remain in place was hotly debated in 2011, however, after the public outcry it was decided per petition to leave the statue on its pedestal where it was. In order to appease the commentary, the explanatory plaque was changed to include a description of his implacability. Beside this prominent statue in Hoorn and the name of the primary school in 
Amsterdam, another recurring topic in the debate is the Coen Tunnel. This tunnel, the Coen Bridge on Highway A8 and the Coen Junction are named after the nearby Coen Port, hence all were named after Jan Pieterszoon Coen (Stiksma and Smit-Kroes 1987). The first part of the tunnel was built in 1966 and an additional three lanes were added and completed in 2014. Besides these public works, many streets across the country are named after Jan Pieterszoon Coen.

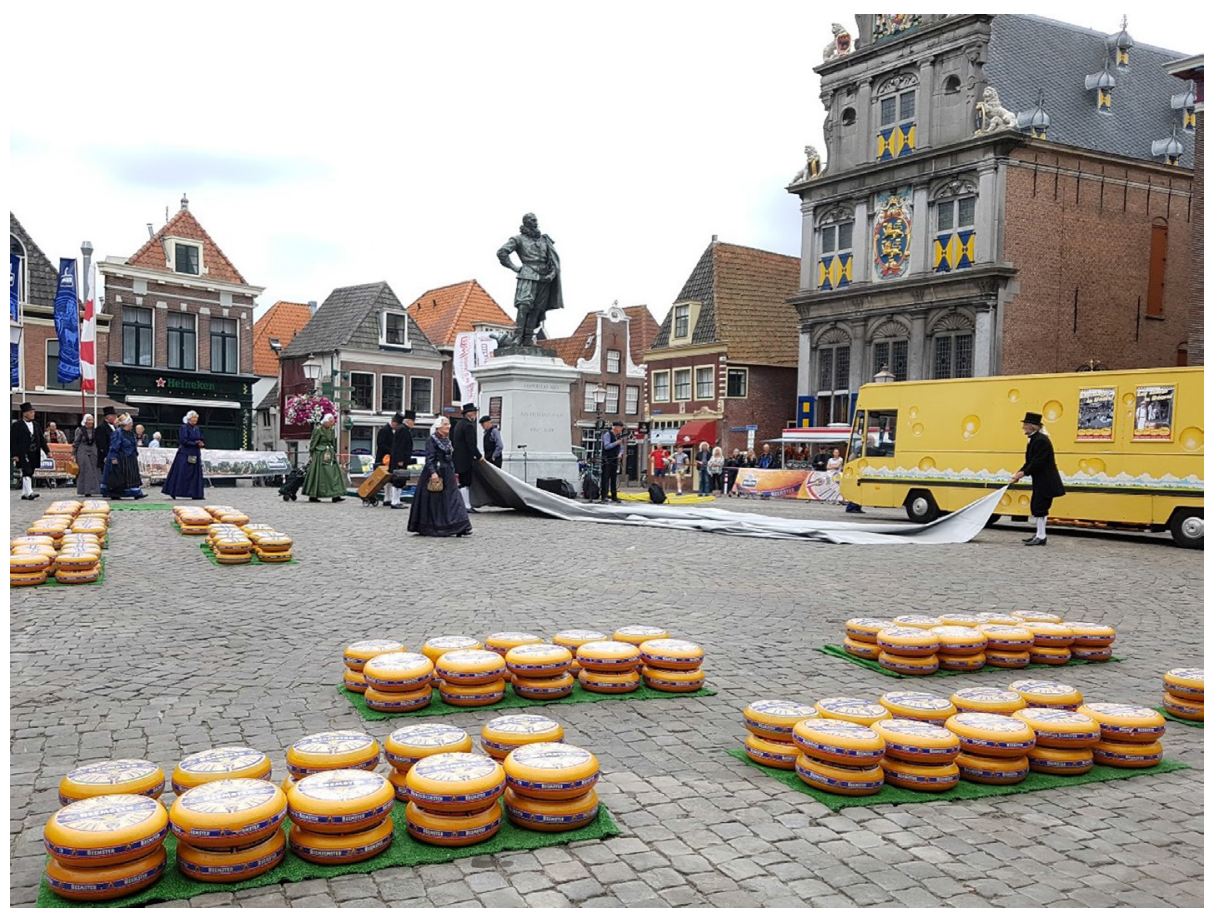

Figure 2. Picture of the central plaza in Hoorn, during a cultural festival commemorating the history of trade in cheeses. The statue of Jan Pieterszoon Coen is clearly visible as the central marker of this plaza, with to the right the Westfries Museum in which an exhibit is includes that describes the controversy surrounding this statue. (Photograph by J. van Donkersgoed).

Alongside the argument that Coen's actions should be "regarded in the spirit of the time", a second argument put forward against removing references to his name from the public sphere is that such an act would be re-writing history (Navis 2018). This leads to the question: whose history is it which is being commemorated? As history is influenced by the perspective of the victorious and powerful, these acts of memorialization and honouring refer to "memorable" episodes in our national history. However, highlighting the positive effects that this history had on the formative period of the Netherlands, which is referred to as the Dutch Golden Age, ignores its shadow side. Therefore, it is exactly those histories which deal with the darker passages of national history, like the violent actions of Jan Pieterszoon Coen, which need 
to be revisited, re-read and re-interpreted to represent a past which includes both sides to form a more complete historical narrative.

As these examples dealing with Coen's commemoration show, there is an increased realization in the Netherlands that a critical analysis of the colonial history of the Netherlands and Indonesia is imperative to facilitate the public debate. That the history of Indonesian history is biased by the involvement of colonial writers is evidenced when the Indonesian scholar Soedjatmoko states: "There is no continuous historical narrative [for Indonesia] nor is there any central point of vision [...] Although for some periods there is a more or less continuous historical narrative, the material is organized according to a viewpoint that was not, and in all fairness could not have been, an Indonesiacentric viewpoint" (Soedjatmoko 1965: xii). This concern is also voiced by the scholar Ann Stoler, when she states that "Dutch colonial archives serve less as stories of a colonial history than as active, generative substances with histories, as documents with itineraries of their own" (Stoler 2009: 1). She continues by stating that, "these archives are not simply accounts of actions [...] [t]hey are records of uncertainty and doubt in how people imagined they could and might make rubrics of rule correspond to a changing imperial world" (Stoler 2009: 4).

Recognizing the bias of a large portion of its collection, the Royal Netherlands Institute of Southeast Asian and Caribbean Studies (Koninklijk Institute voor Taal-, Land- en Volkenkunde, KITLV) has engaged in several projects to collect data from outside its existent colonial archive, for example, through the "Recording the Future" project which was launched in 2003, conducted by Indonesian team members in cooperation with the Indonesian Institute of Sciences (Lembaga Ilmu Pengetahuan Indonesia, LIPI) and Offstream Film. Its aim is to "establish an audio-visual archive of everyday life in Indonesia during the 21st century, and to conduct research on daily life through this archive" (Steijlen n.d.). More recently and critically, the KITLV project "Decolonisation, Violence and War in Indonesia, 1945-1950", in cooperation with the Dutch Institute for Military History (Nederlands Instituut voor Militaire Geschiedenis, NIHM) and the Institute for War, Holocaust and Genocide Studies (Nederlands Institute for Oorlogsdocumentatie, NIOD) addresses a violent and dark passage of history in the form of the atrocities perpetrated by the Dutch on Indonesian soil (KITLV, NIHM, and NIOD n.d.). This project not only promotes itself as having a "strong international character", it also offers a participatory aspect whose aim is to collect more data about this particular period through interviews with "witnesses" (KITLV, $\mathrm{NIMH}$, and NIOD n.d.).

As stated earlier by Soedjatmoko (1965) and Stoler (2009), in particular the history of Indonesia from roughly the 1600-1950s, has largely been written by Dutch colonial officials or others employed by the Dutch state. Merely reproducing these documents will therefore in effect re-instate the dominant narrative of the colonizer over the interpretation of the local and national agents. In order to address this issue, a large archive is needed which includes 
not only the written material collected and produced by Dutch officials, but also material which includes documents, photos and other memorabilia which have been saved by generations who have had personal ties to the Banda Islands. This type of archival material would facilitate the conversation which is discussing how this history is of relevance to contemporary society.

\section{ARCHIVE FOR BANDA}

The historical overview of the Banda Islands as presented in this article is based primarily on the Dutch archival and historical material, however I have been able to gather information from several other groups which have historical ties with and an interest in the history of the Banda Islands. Some of the main groups are composed of the contemporary residents of the Banda Islands, the "original Bandanese" who live in the Kei Islands and the descendants of perkeniers who live in the Netherlands. Moreover, this historical overview has been focused on those parts of the past which still resonate in the contemporary Banda Islands, either through the tangible markers like the fortifications and structures connected to the perken, or intangible remnants like its effect on the contemporary demography and cultural practices. In other words, this history reveals how different ethnic, racial and cultural groups which have contributed to the current heritage, culture and demography of the Banda Islands.

An example of this hybrid history is Pongky van den Broeke, known in the Banda Islands as "the last perkenier". After winning a lawsuit, his father was able to regain part of the former plantation Groot Waling, which had been in their family for twelve generations. According to Van de Wall, his ancestor was Pieter van den Broeke, a Dutchman who arrived in Banda on his ship the Nassau to help conquer the island Ay with Admiral Reynst in 1615 (Van de Wall 1934: 562). He further says that Van den Broeke, who helped secure Asian trade for the VOC, left his mark in Banda through his lineage before dying during the siege of Malacca in 1641. However, Pongky van den Broeke states that it was not Pieter from whom his family is descended, but another family member Paulus van den Broeke (Oude Elferink 2017). This short personal narrative showcases the close connection between the current residents of the Banda Islands and the Dutch. When I met descendants from Dutch perkenier families who were visiting the Banda Islands, it was fascinating to hear how openly they were received by the Bandanese. Often, they were pointed in the direction of far-distant relatives and, even though the language barrier prevented an intellectual exchange, they still felt welcomed by the Bandanese.

However, if the Bandanese are questioned about the events of 1621 or Jan Pieterszoon Coen, they will not have a good word to say about the past Dutch colonists. Despite this, in the eyes of the Bandanese this history seems to be disconnected from the present as contemporary Dutch visitors are regarded as welcome guests. The Dutch tourists not only offer an extra source of income, but they boost the Bandanese sense of pride in their history and heritage which attracts these (and other foreign) visitors from far away. Moreover, it is a starting point for engaging the visitor, pointing out cultural connections 
and exploring common vocabulary (the Bandanese local language shares several Dutch vocabularies like brood (bread), lepe (spoon), and straat (street)).

Through my work in the Banda Islands, I became acquainted with the Dutch family De Vries, whose paternal head was born on the Island Banda Besar and who feel strong ties to the land, history, and heritage of the Banda Islands. Down the decades this Dutch family has gathered many documents and, during their visits to the Banda Islands, they gladly show these resources to interested Bandanese people. During one of these exchanges, Tanya Des Alwi, the current president of the Banda Naira Culture and Heritage Foundation (Yayasan Warisan dan Budaya Banda), enthusiastically initiated the idea of a "perkeniers museum", in which photos and other archival material could be displayed for visitors to see and learn about this part of Banda's history. This idea is an example of an interaction indicating that there is an interest from the residents of the Banda Islands in gaining access to these materials which are currently held in the Netherlands. Moreover, in my interactions with Bandanese (either those who reside in the Banda Islands or elsewhere), during which I question them about the Bandanese history, several informants have excused themselves to come back with either old photographs of how the forts looked decades ago, or with family documents from the colonial era in which some sort of interaction between the Bandanese residents and the Dutch colonial government has been preserved. These exchanges show there is a genuine interest on both sides to exchange information.

The idea of the De Vries family and Des Alwi to create a perkeniers museum stuck in the back of my mind, both because of its potential to describe a part of the history of the Banda Islands which is currently minimally presented in the local museum and its possible adverse execution as a commemoration of the "golden days of the perken". This latter perspective might be a result (although unintended), as most of the documents from the colonial era were written by the Dutch colonists and the project would be conducted from a top-down Dutch initiative. My interest in the presentation of Dutch colonial heritage prompted me to visit Curaçao, in a quest to examine how museums there negotiate these histories. In particular, I want to draw attention to the Savonet Museum Curaçao, the latest museum housed in a former plantation owner's house. Its permanent exhibit is dedicated to the lives of the plantation owners as well as the slaves, whose stories are told side by side. This approach is a contrast to the other collections in Curaçao, as they are presented from one or the other perspective, but not both. The act of bringing the objects, documents and photos together shows a more balanced interpretation of the history of the site, demonstrating that different lives, memories and stories do exist alongside each other. Their approach has provided the inspiration for the idea which I shall present in the following sections, in which I explain how methods from the Digital Humanities can be utilized to create a digital platform on which a new collective archive dealing with the colonial past of the Banda Islands can be established using crowd-sourcing and crowd-mapping tools. This digital platform will allow the documents and memories of the 
Dutch perkenier-families to exist alongside those of the Bandanese residents and those in the diaspora.

\section{ToOls From the Digital Humanities}

The desire to preserve is a central theme in the field of heritage studies, and some claim that this field has expanded so rapidly during the past few decades because this need for preservation strengthens as the world is undergoing rapid changes on local and global scales. Critical heritage scholar Rodney Harrison has stated that our late-modern period is characterized by this "sense of crisis and uncertainty", which results in the increased efforts to preserve old materials and traditions without being able to articulate what their possible value might be (Harrison 2013:3). He therefore urges those who are involved in heritage management to think "of heritage as a creative engagement with the past in the present [and focus] our attention on our ability to take on an active and informed role in the production of our own 'tomorrow'" (Harrison 2013: 4). Contrary to Harrison's somewhat negative view of this ever-expanding need for preservation, I argue that the creation of a new digital archive can engage people with historical material and this could result in a realization of new values and meeting ground for today's debate.

The reason I propose to employ an approach from Digital Humanities to engage with this difficult history and the heritage of the Banda Islands is neatly summed up by Burdick (2012) in their preface of the handbook Digital Humanities:

Digital Humanities represents a major expansion of the purview of the humanities precisely because it brings the values, representational and interpretive practices, meaning-making strategies, complexities, and ambiguities of being human into every realm of experience and knowledge of the world. It is a global, transhistorical and transmedia approach to knowledge and meaning-making. (Burdick 2012: vii).

The potential of the methods in Digital Humanities are multifold, and most importantly for the material concerning the Banda Islands, they promise that its methods will be inclusive, provide a platform in which multiple narratives are able to exist alongside each other and facilitate the historical ambiguity which is the inevitable result when different perspectives meet. There is special need within Indonesian Studies for a platform on which multiple histories can co-exist, because most of the archival material and sources for scholarship were gathered by "outsiders". Moreover, as Burdick explains: "In contrast with most traditional forms of scholarship, digital approaches are conspiciously collaborative and generative, even as they remain grounded in the traditions of humanistic inquiry" (Burdick 2012: 26).

Crowd-sourcing is the main tool from the Digital Humanities which could contribute to the establishment of a collaborative digital archive for Banda's colonial past. The coining of this term has been attributed to Jeff Howe, whose White Paper definition is "Crowdsourcing is the act of taking a job 
traditionally performed by a designated agent (usually an employee) and outsourcing it to an undefined, generally large group of people in the form of an open call"(Howe 2006). Claire Ross has expanded his definition by referring to Wikipedia, as this is probably the best-known and most widely accessed crowd-sourcing platform as it heavily depends on crowd-sourced content (Ross 2012: 27). Beyond Howe's business objectives, the tool has gathered support within academia on account of its quality as a complex system, as the crowd is able to produce a kind of group intelligence based on collaboration or competition (Kapetanios 2008). However, as the term originated as a corporate tool, it does contain some exploitative aspects as crowd-sourcing can be framed as "free labour" to tackle academic workflows (Arbuckle, Mauro, and Powell 2017: 8-9).

Although not all scholars think that crowd-sourcing is appropriate to scholarly uses, Claire Ross argues that there has also been a rise in the use and support of crowd-sourcing in academia as this has the "ability to transform information and promote dialogue between disparate users" (Ross 2012: 28). Mia Ridge has confirmed the positive effect crowd-sourcing can have, especially in the case of cultural heritage, stating "Cultural heritage crowdsourcing projects ask the public to undertake tasks that cannot be done automatically, in an environment where the activities, goals (or both) provide inherent rewards for participation, and where their participation contributes to a shared, significant goal or research interest" (Ridge 2014: 3). By choosing the example between the De Vries family and Tanya Des Alwi, I have indicated that there is an interest from both sides of history to share information. The rewards for participation are present, as the exchange of information will allow increased access to this material as well as an opportunity to expand the boundaries of the historical knowledge of all parties involved. Moreover, the ability to connect "disparate users", as Ross mentions, is of special interest in this case study, as there are knowledge-keepers in several geographical locations with different historical perspectives and archival material.

\section{CROWD-SOURCING AND CROWD-MAPPING}

Many collections have digitalized their collections and allow the public to access the result in one way or another. Moreover, the idea of connecting it to a geographical map has been successfully executed by the project Atlas of Mutual Heritage (AMH n.d.). The Atlas of Mutual Heritage is a database with information, maps, drawings, prints, and paintings of locations related to the Dutch East India Company and the Dutch West India Company (West Indische Compagnie, WIC), mainly comprising the extensive collections of the Dutch National Archive (Nationaal Archief), the Dutch Cultural Heritage Agency (Rijksdienst voor het Cultureel Erfgoed, RCE), the Rijksmuseum in Amsterdam and the Dutch Royal Library (Koninklijke Bibliotheek). This digital archive is connected to a virtual map; however, it still relies on the pre-existing collections of established institutions. Another example of such 
a website is Pleiades, which "is a community-built gazetteer and graph of ancient places"(Bagnall et al. 2006). This website publishes peer-reviewed contributions, and provides services "for finding, displaying, and reusing that information under open license".

Contrary to these expert-based digital collections which are connected to maps, I want to discuss a sub-type of crowd-sourcing known as crowd-mapping. It gained popularity as a tool when Ushahidi, a Kenyan website, launched the initiative to develop map reports in Kenya after the post-election violence in 2008. This website "provides software and services to numerous sectors and civil society to help improve the bottom up flow of information" (Ushahidi 2008). Although crowd-mapping gains most of its traction "to provide realtime, interactive information on events such as wars, humanitarian crises, crime, elections, or natural disasters (the results are sometimes referred to as crisis maps)" (Quaintance 2011), it can also be used as a community-based tool to create interactive informative maps about their environment.

An example of this usage was introduced to me in Curaçao by Ace Suares, who advised me to use the application Maps.me instead of Google Maps to find my way around the island. He explained to me that the application Maps.me contains more information than the Google Maps, as the former was created collaboratively by volunteers from Curaçao, while Google Maps functions on a business model and there are too few business incentives to develop an accurate map of Curaçao. The project was further explained to me by Milo van der Linden, co-founder of the OpenGeoGroep, a Dutch collective of experts, consultants, and professionals in open source software. He had led the community-mapping workshop in Curaçao and explained that an important aspect of the projects he has conducted is its implications for local tourism. Using the basic map from OpenStreetMap, Maps.me allows users to add local businesses, like guesthouses, small restaurants or other local businesses to the online map. As Maps.me allows users to download the map for offline usage, tourists can download the map of the entire island and use it as they explore the island. Moreover, he alerted me to the fact that Indonesia has an active group engaged in improving the OpenStreetMap, called OpenStreetMap Indonesia.

OpenStreetMap Indonesia consists of volunteers who have conduct surveys using GPS, digitalize satellite imagery and collect publicly available geographical data to be added to this open-source map (OpenStreetMap Indonesia n.d.). They emphasize their importance as, especially in the case of Indonesia, there might not be a commercial incentive for mapping companies to develop an accurate map for remote or economically disadvantaged areas. This reasoning can be applied to the Banda Islands, a remote area which is inaccurately presented on Google Maps. Moreover, Openstreetmap Indonesia has already expressed their interest in working together with the students of the local Hatta-Sjahrir College to develop the digital map of the Banda Islands. 


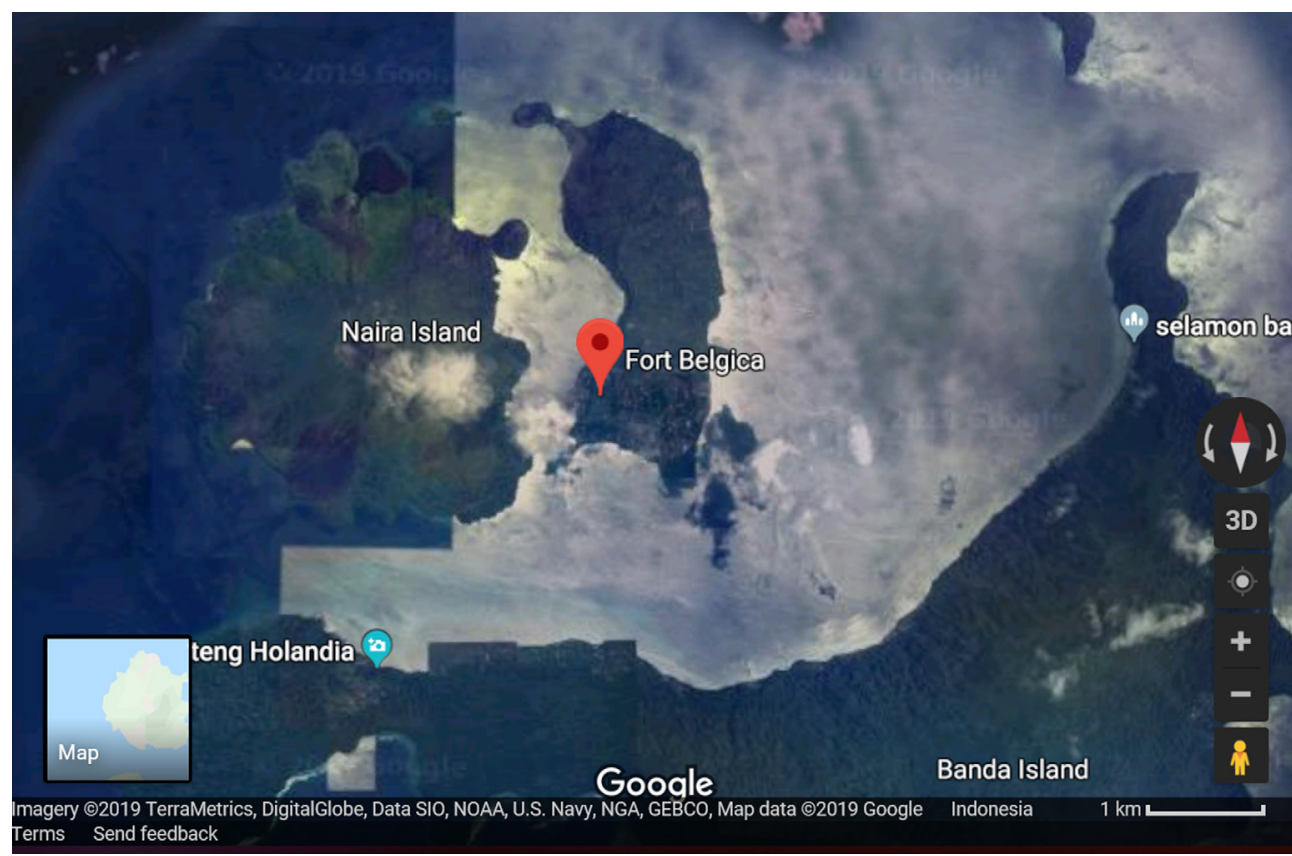

Figure 3. This screenshot shows a section of the Banda Islands, include the Islands Banda Besar (on the image referred to as Banda Island), Banda Neira (not named on this map, but indicated by the attraction "Fort Belgica") and the volcano Gunung Api (here referred to as Naira Island). The arrow indicates an island, according to Google Maps, however there is not island located here. (Source: Google Maps).

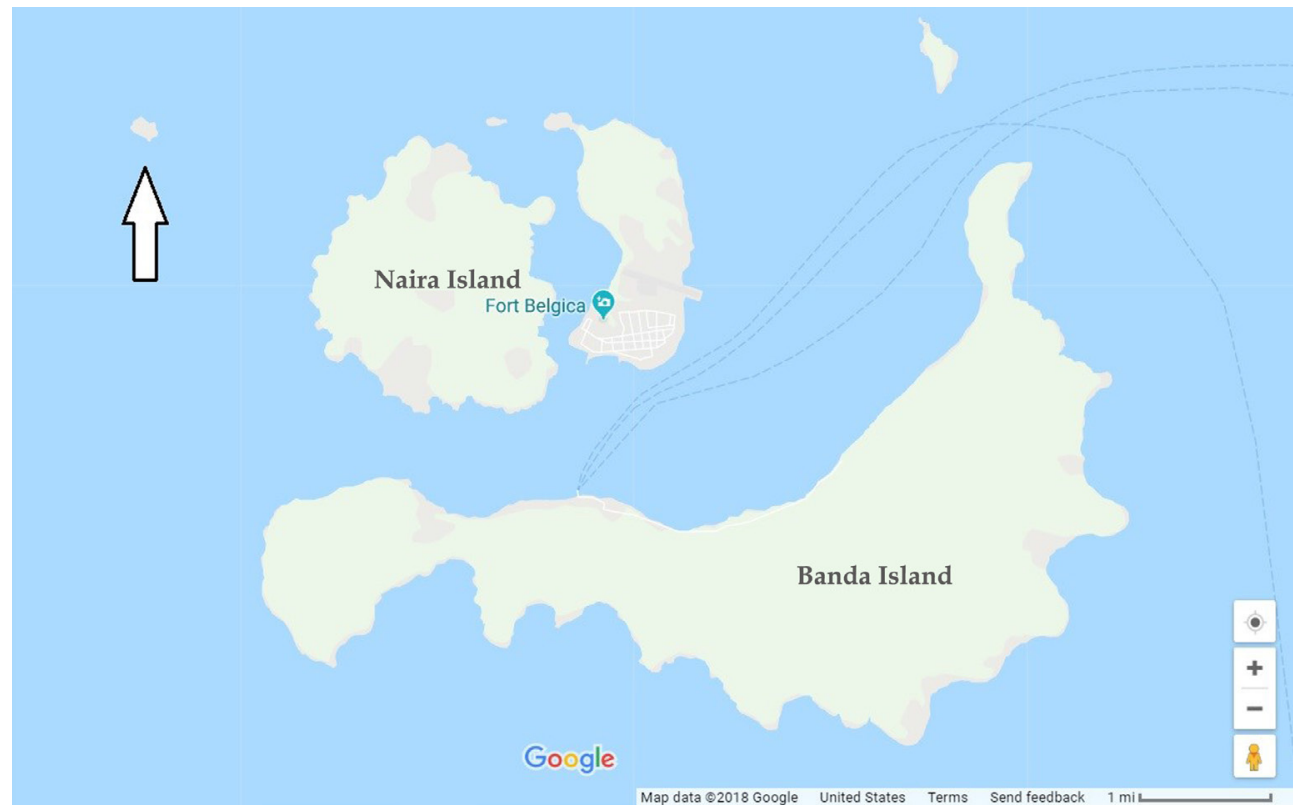

Figure 4. This screenshot shows the same range as Figure 1 but in satellite view. On the place where Google Maps drew an island a cloud is visible, which is the probable cause for the error. (Source: Google Maps). 
Figures 3 and 4 show a section of the Banda Islands from Google Maps in both map and satellite view. The first error I want to point out is that the islands are incorrectly named. Admittedly the islands are known by multiple names, Banda Besar, for example, is also referred to as Lontor or in colonial documents as Groot Banda, but none of these names is used on the current Google Maps and a generic "Banda Island" is used. Besides this, next to the volcano island Gunung $\mathrm{Api}^{5}$ is an island which does not exist in reality.

On the satellite view, the location of the supposed island is covered by a cloud, which is probably the reason for this error. If this section is compared to the same area on OpenStreetMap, however, it is as clear as daylight that this latter map already contains more accurate information (see Figure 5).

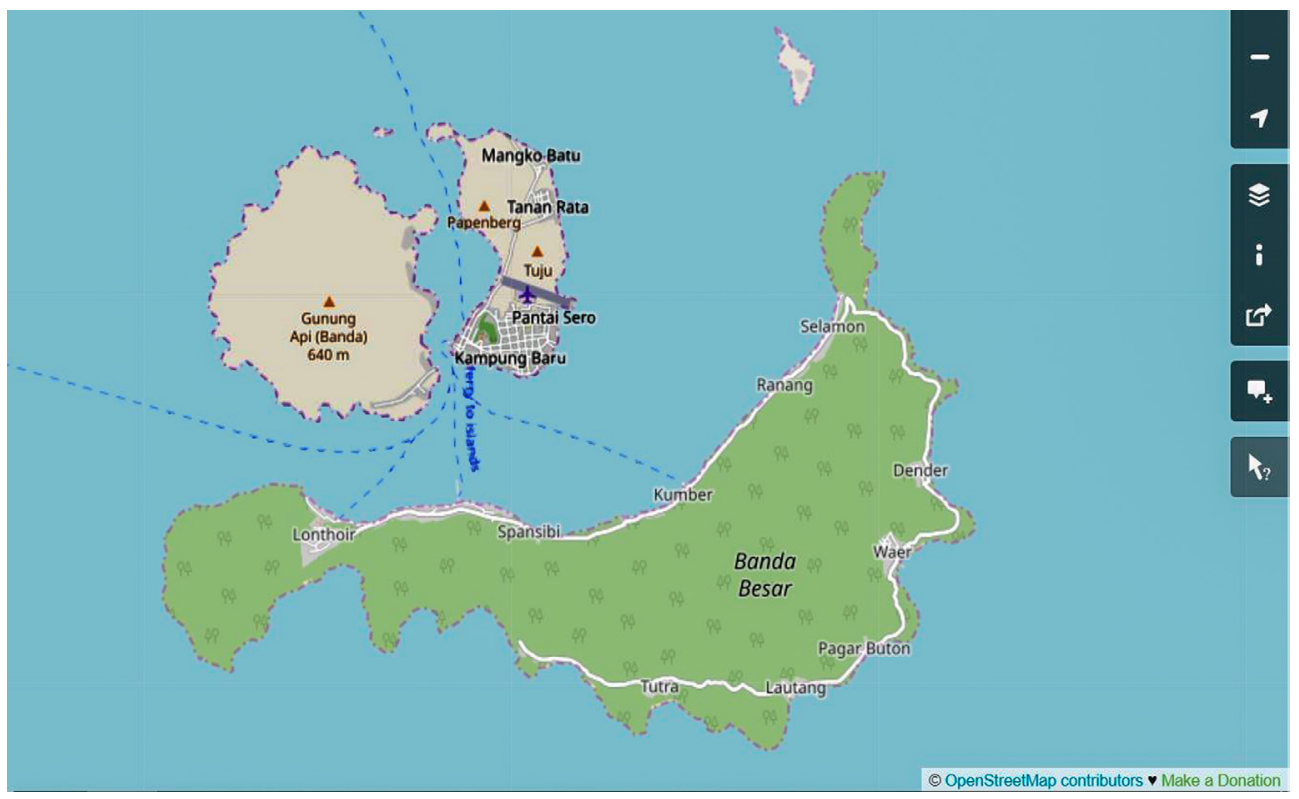

Figure 5. This is a screenshot of the same section, but then from OpenStreetMap. The non-existent island is not present, moreover, the islands are named correctly and there is more information included about the various villages. (Source: OpenStreetMap).

Besides the need for a more accurate map of the Banda Islands, there is a potential to create an interactive map which could be tied to a digital archive. On account of the relatively small scale of the Banda Islands, it would take little effort to create an interactive map on which the historical maps of the islands are plotted on top of the contemporary map, allowing visitors and residents to compare their current bearings with a historical setting in real-time. These historical maps can act as layers which can be turned on and off, while the GPS signal of the phone continues to indicate the position of the user.

Alongside this interface which connects different historical maps to the

5 On the figure this is indicated by Google as Naira Island, but depending on how far you zoom in, other names including Bandanaira, Banda Api, and Pulau Gunung Api appear. 
present, certain locations could contain their own digital collection. This is the archive which would result from crowd-sourcing, containing old documents and photographs from anyone who is able and willing to contribute to this open source platform. For example, when the user is interested in seeing Fort Nassau at different time periods, he or she could click on the folder which is linked to the geographical location to access the files which have been submitted by other users. In an ideal world, this application would feature certain tools to make it easy for everyone to contribute to each mini collection. As Bandanese residents are active on Facebook and are enthusiastic photographers, a simple interface could allow them to take a picture of their old documents or photograph and upload them directly to the online archive. This system would allow for a bottom-up method of data collection. Through simple tags, like the name of the location, date and/or names associated with the file, other users would then be able search for the material in which they are interested.

\section{CONCLUSION}

The history of the Banda Islands is currently a hot topic for debate in the Netherlands, in which the figure of Jan Pieterszoon Coen looms large. Because of his prominent role in the Bandanese massacre, his name has only negative connotations for the Bandanese residents. The events of 1621 led not only to the exodus of the original Bandanese, but also to the forced labour of imported slaves who were brought in from across the Indies to work on the nutmeg perken. Moreover, the perken system which was introduced by Coen included an expansion in the construction of fortifications to "protect the trade". Besides this material heritage, the demography of the current Bandanese residents shows that the Dutch colonizers also left their mark by intermarrying with the local population and other foreign merchants in the islands. This has produced a socially hierarchical but none the less multi-cultural society still visible in the immaterial heritage of the Bandanese. These material and immaterial heritages mark the contemporary cultural landscape of the Banda Islands and are currently under review by local and national agents in an effort to increase the tourism industry.

As these remote islands are expanding their incentives to encourage tourists to visit their colonial remnants, a new interactive map would assist them in promoting a multi-faceted history as well as engaging their visitors in an experience of Bandanese culture and cuisine. An interactive map would provide additional promotion for local businesses, like guesthouses, food stalls, souvenir shops and other attractions. Moreover, by utilizing a crowd-sourcing tool to create a digital archive, the interface can accumulate stories, images and documents pertaining to particular sites in the Banda Islands. For example, the collection of archival material about Fort Nassau will unquestionably include stories of the Bandanese massacre, as well as give indications of its later function as a tennis court for perkenier families. Both narratives are valid and are part of the fabric of the site, and a digital archive 
will offer the platform on which these stories can be gathered on a level playing field. In turn, this could facilitate a conversation about how these histories are dealt with in contemporary society and provide food for thought as the public debate about Dutch colonial heritage and acts of commemoration continues.

\section{BIBLIOGRAPHY}

AMH. n.d. "Atlas of Mutual Heritage”. [Http:/ / www .atlasofmutualheritage. nl/en/; accessed on 30-9-2018.]

Arbuckle, Alyssa, Aaron Mauro, and Daniel Powell. 2017. "Tracing the movement of ideas; Social knowledge creation in the humanities", in: Alyssa Arbuckle, Aaron Mauro, and Daniel Powell (eds), Social knowledge creation in the humanities, pp. 1-28. Toronto, Ontario: Iter Press. [New Technologies in Medieval and Renaissance Studies 7.]

Bagnall, Roger, Richard J. A. Talbert, Sarah Bond, Jeffrey Becker, Tom Elliott, Sean Gillies, Ryan Horne, et al. 2006. "Pleiades; A community-built gazetteer and graph of ancient places". [Pleiades; The STOA consortium; http:/ / pleiades.stoa.org/.]

Berg, Joop van den. 1995. Het verloren volk; Een geschiedenis van de Banda-eilanden. 's-Gravenhage: BZZTôH.

Burdick, Anne. 2012. Digital Humanities. Cambridge, Mass.: MIT Press.

Chijs, J.A. van der. 1886. De vestiging van het Nederlandsch gezag over de Banda eilanden, 1599-1621 met een kaart. Batavia: Bataviaasch Genootschap van Kunsten en Wetenschappen.

Crawfurd, John. 1856. A descriptive dictionary of the Indian Islands E Adjacent Countries. London: Bradbury \& Evans. [Http://archive.org/details/ ldpd_6769878_000.]

Gaastra, F.S. 1991. De geschiedenis van de VOC. Zutphen: Walburg Pers.

Hanna, Willard Anderson. 1978. Indonesian Banda; Colonialism and its aftermath in the nutmeg Islands. Philadelphia, PA: Institute for the Study of Human Issues.

Harrison, Rodney. 2013. Heritage; Critical approaches. Milton Park, Abingdon; New York: Routledge.

Howe, Jeff. 2006. "Crowdsourcing; A definition", in: Jeff Howe, Crowdsourcing; The power of the crowd is driving the future of business. [Http:/ / www. crowdsourcing.com/cs/2006/06/crowdsourcing_a.html.]

Kaartinen, Timo. 2010. Songs of travel, stories of place; Poetics of absence in an eastern Indonesian society. Helsinki: Suomalainen Tiedeakatemia = Academia Scientiarum Fennica.

Kapetanios, Epaminondas. 2008. “Quo Vadis computer science; From turing to personal computer, personal content and collective intelligence", Data $\mathcal{E}$ Knowledge Engineering 67 (2): 286-292. [Https://doi.org/10.1016/j. datak.2008.05.003.]

KITLV, NIMH, and NIOD. n.d. "Call for your personal stories and experiences", Decolonization, violence and war, Indonesia 1945-1950. [Https:/ / www.ind4550.org/en/call-your-personal-stories-and-experiences; accessed on 20-92018.] 
Masyarakat Waer- Ohoitel, Banda Ely. 2014. Sejarah perjalanan Keluarga Banda Ely (Wandan) dan perolehan tanah El. Banda Ely, Kei Islands, Indonesia.

Multatuli and Garmt Stuiveling. 1950. Volledige werken [door] Multatuli [pseud. Bezorgd door G. Stuiveling]. Amsterdam: G.A. van Oorschot.

Navis, Jan Willem. 2018. "Historici hard over aantasting geschiedenis: 'Stop de vervalsing'”, Telegraaf, 17 January, sec. Binnenland.

Oostindie, Gert. 2018. Postkoloniale Beeldenstormen. Nijmegen: Uitgeverij Vantilt. OpenStreetMap Indonesia. n.d. “Tentang OpenStreetMap (OSM)”. [Https:/ / openstreetmap.id/about/tentang-openstreetmap/; accessed 30-9-2018.]

Oude Elferink, Eva. 2017. “De laatste perkenier op de Banda-Eilanden”, NRC, 3 August, sec. Buitenland.

Quaintance, K. 2011. "Concepts to know; Crowdmapping". [Http:/ / kimoquaintance.com/2011/09/04/concepts-to-know-crowdmapping/.]

Ridge, Ms Mia. 2014. Crowdsourcing our cultural heritage. Farnham: Ashgate Publishing. [First edition.]

Ross, Claire. 2012. "Social media for Digital Humanities and community engagement", in: Claire Warwick, Melissa M. Terras, and Julianne Nyhan (eds), Digital Humanities in practice, pp. 23-46. London: Facet Publishing in association with UCL Centre for Digital Humanities.

Sjahrir, Sutan. 1946. Indonesische overpeinzingen. Amsterdam: de Bezige Bij.

Smith, Laurajane. 2006. Uses of heritage. New York: Routledge.

Soedjatmoko. 1965. An introduction to Indonesian historiography. Ithaca, NY: Cornell University Press.

Steijlen, Fridus. n.d. "Recording the Future". [KITLV (blog); http:/ /www. kitlv.nl/research-projects-recording-the-future/; accessed on 20-9-2018.]

Stiksma, Kees, and N. Smit-Kroes. 1987. Tunnels in the Netherlands; Underground transport connections. Amsterdam: Illustra.

Stoler, Ann Laura. 2009. Along the archival grain; Epistemic anxieties and colonial common sense. Princeton, NJ: Princeton University Press.

Tulkens, Joyce. 2007. Jan Pieterszoon Coen. Utrecht: Uitgeverij Kok.

Ushahidi. 2008. "About Ushahidi". [Https://www.ushahidi.com/about.]

Valentijn, François. 1856. François Valentijn's oud en nieuw Oost-Indiën. Volume 1. [Https://archive.org/details/franoisvalentij00valegoog/page/n6; University of Michigan Library.]

Wall, V.I. van de. 1934. "Bijdrage tot de geschiedenis der Perkeniers 1621-1671", Tijdschrift voor Indische taal-, Land-en Volkenkunde 74: 516-580.

Winn, Phillip. 2005. "Tanah berkat (blessed land); The source of the local in the Banda Islands, Central Maluku"', in: Thomas Reuter (ed.), Sharing the earth, dividing the land; Land and territory in the Austronesian world, pp. 113133. [ANU E Press.]

Winn, Phillip. 2010. "Slavery and cultural creativity in the Banda Islands", Journal of Southeast Asian Studies 41(03): 365-389.

Wit, Augusta de. 1914. Natuur en menschen in Indië; Met 45 ill. Amsterdam: De Maatschappij voor Goede en Goedkoope Lectuur.

Wright, H.R.C. 1958. "The Moluccan spice monopoly, 1770-1824”, Journal of the Malayan Branch Royal Asiatic Society 31(4): 1-127. 